\title{
Az extrém alacsony születési súlyú koraszülöttek hyperglykaemiájának korai és késői szövődményei
}

\author{
Turai Réka dr. ${ }^{1}$ - Schandl Márton Ferenc ${ }^{1}$ - Dergez Timea dr. ${ }^{2}$ \\ Vass Réka Anna dr. ${ }^{1,3,6}$. Kvárik Tímea dr. ${ }^{1,3}$ - Horányi Eszter ${ }^{1,3}$ \\ Balika Dorottya ${ }^{1,3}$ - Mammel Barbara dr. ${ }^{1,3}$. Gyarmati Judit dr. ${ }^{1}$ \\ Fónai Fruzsina dr. ${ }^{1}$ - Vida Gabriella dr. ${ }^{1}$ - Funke Simone dr. ${ }^{1}$ \\ Gaál Valéria dr. ${ }^{4}$. Reglődi Dóra dr. ${ }^{3,5}$. Ertl Tibor dr. ${ }^{1,6}$
}

\footnotetext{
${ }^{1}$ Pécsi Tudományegyetem, Általános Orvostudományi Kar, Klinikai Központ, Szülészeti és Nőgyógyászati

Klinika, Neonatológiai Tanszék, Pécs

${ }^{2}$ Pécsi Tudományegyetem, Általános Orvostudományi Kar, Bioanalitikai Intézet, Pécs

${ }_{3}^{3}$ Pécsi Tudományegyetem, Általános Orvostudományi Kar, Anatómiai Intézet, Pécs

${ }^{4}$ Pécsi Tudományegyetem, Általános Orvostudományi Kar, Klinikai Központ, Szemészeti Klinika, Pécs

${ }^{5}$ MTA-TKI PACAP Kutatócsoport, Pécs

${ }^{6}$ MTA-PTE Humán Reprodukciós Kutatócsoport, Pécs
}

\begin{abstract}
Bevezetés: Az újszülött intenzív osztályok múködésének köszönhetően az extrém alacsony súlyú koraszülöttek perinatalis mortalitása jelentősen csökkent. Fontos feladat a korai és késői szövődmények felismerése.

Célkitüzés: A hyperglykaemia (vércukorszint>8,5 mmol/1) előfordulási gyakoriságát, a korai és késői komplikációkat feltárva kapcsolatot kerestünk a hyperglykaemia és a szövődmények kialakulása között.

Módszer: A 2014. január 1. és 2017. december 31. közötti periódusban született, 1000 g alatti súlyú 188 koraszülött klinikai adatait elemeztük. Meghatároztuk a hyperglykaemia, a retinopathia, az agyvérzés, valamint a bronchopulmonalis dysplasia gyakoriságát. Állatkísérleteinket Sprague Dawley patkányokon végeztük. A hyperglykaemiás állapotot intraperitonealis sztreptozotocininjekció adásával értük el $(100 \mathrm{mg} / \mathrm{ttkg})$. A 7 . életnapon az aortát eltávolítottuk, szövettani metszeteket készítettünk, melyeket hematoxilin-eozin oldatokkal festettünk. A falvastagságot a QCapture Pro 7 képelemző programmal mértük.

Eredmények: Az 1000 g alatti születési súlyú koraszülöttek gesztációs kora és születési súlya 27,1 $\pm 2,2$ hét, illetve $814,9 \pm 151,9$ g volt, közülük 33 exitált (17,5\%). Hyperglykaemiát 62 esetben igazoltunk $(32,9 \%)$, inzulinkezelést 43 esetben alkalmaztunk $(22,8 \%)$. A hyperglykaemiás csoport gesztációs kora, születési súlya szignifikánsan alacsonyabb volt $(\mathrm{p}<0,001)$, a súlyos retinopathia előfordulása gyakoribb $(\mathrm{p}=0,012)$, az inzulinkezeltek mortalitása magasabb $(\mathrm{p}=0,02)$ volt, mint a normoglykaemiás koraszülötteké. A túlélő gyermekeket vizsgálva $(\mathrm{n}=155)$ logisztikus regressziós analízissel megállapítottuk, hogy a hyperglykaemia jelentős kockázati tényező a súlyos retinopathia kialakulásában $(\mathrm{p}<0,001)$. Állatkísérletes modellen megfigyeltük, hogy a neonatalis hyperglykaemia az aortafal jelentős megvastagodását okozza.

Következtetés: Retrospektív és állatkísérletes vizsgálataink eredményei arra hívják fel a figyelmet, hogy hyperglykaemia gyakran alakul ki extrém alacsony súlyú koraszülöttekben; gondozásuk során a szemészeti kontroll mellett a vesemúködés és a vérnyomás ellenőrzése is fontos feladat.
\end{abstract}

Orv Hetil. 2019; 160(32): 1270-1278.

Kulcsszavak: extrém alacsony születési súly, neonatalis hyperglykaemia, szövődmények

\section{Early and late complications of hyperglycemic extremely low birth-weight infants}

Introduction: During recent decades, the perinatal mortality of extremely low-birth weight infants has decreased. An important task is to recognize complications of prematurity.

Aim: We made an attempt to explore the relationship between complications of prematurity and neonatal hyperglycemia. 
Method: From 1 January 2014 to 31 December 2017, 188 infants with birth weight below 1000 g were admitted. For each infant, the frequencies of hyperglycemia (blood glucose $>8.5 \mathrm{mmol} / \mathrm{l}$ ), retinopathy of prematurity, intraventricular hemorrhage, and bronchopulmonary dysplasia were determined. Animal studies were performed in Sprague Dawley rats. Hyperglycemia was achieved by intraperitoneal injection of streptozotocin $(100 \mathrm{mg} / \mathrm{kg})$. On the 7th day of life, aorta sections were prepared and stained with hematoxylin eosin. Wall thickness was measured using QCapture Pro 7 image analysis software.

Results: The mean \pm SD gestational age and birth weight were $27.1 \pm 2.2$ weeks and $814.9 \pm 151.9 \mathrm{~g} ; 33$ infants (17.5\%) died. Hyperglycemia was confirmed in 62 cases $(32.9 \%)$, and insulin treatment was given to 43 infants $(22.8 \%)$. The gestational age and birth weight of the hyperglycemic infants were significantly lower $(\mathrm{p}<0.001)$, the incidence of severe retinopathy $(\mathrm{p}=0.012)$ and the mortality of insulin-treated patients were higher $(\mathrm{p}=0.02)$ than in normoglycemic infants. Among survivors $(\mathrm{n}=155)$, we found by logistic regression analysis that hyperglycemia was a risk factor for severe retinopathy $(\mathrm{p}<0.001)$. In the rat model, neonatal hyperglycemia caused significant thickening of the aortic wall.

Conclusion: Our studies indicate that hyperglycemia is common in extremely low birth-weight infants. Monitoring of these infants for retinopathy of prematurity, kidney dysfunction, and hypertension is recommended.

Keywords: extremely low birth-weight, neonatal hyperglycemia, complications

Turai R, Schandl MF, Dergez T, Vass RA, Kvárik T, Horányi E, Balika D, Mammel B, Gyarmati J, Fónai F, Vida G, Funke S, Gaál V, Reglődi D, Ertl T. [Early and late complications of hyperglycemic extremely low birth-weight infants]. Orv Hetil. 2019; 160(32): 1270-1278.

(Beérkezett: 2019. február 21.; elfogadva: 2019. március 28.)

\begin{abstract}
Rövidítések
ANOVA = (analysis of variance $)$ varianciaanalízis; ÁOK = Általános Orvostudományi Kar; BPD = bronchopulmonalis dysplasia; CRIB score $=($ clinical risk index for babies $)$ a klinikai állapot súlyosságát jelző pontszám; ELBW $=$ (extremely low birth-weight) $1000 \mathrm{~g}$ alatti születési súly; $\mathrm{HG}=$ hyperglykaemiás, extrém alacsony születési súlyú koraszülött; HG-IK = hyperglykaemiás, inzulinkezelésben részesült, extrém alacsony születési súlyú koraszülött; HG-NIK = hyperglykaemiás, inzulint nem kapott, extrém alacsony születési súlyú koraszülött; IGFl $=($ insulin-like growth factor 1$)$ inzulinszerü növekedési faktor-1; IL6 = interleukin-6; IVH = intraventricularis haemorrhagia; $\mathrm{NEC}=$ nekrotizáló enterocolitis; $\mathrm{NF}_{\kappa} \mathrm{B}=$ nukleárisfaktor-kappa-B; $\mathrm{NG}=$ normoglykaemia $; \mathrm{PKC}=$ proteinkináz $\mathrm{C} ; \mathrm{PTE}=$ Pécsi Tudományegyetem; $\mathrm{PVL}=$ periventricularis leukomalacia; $\mathrm{ROP}=$ retinopathia praematurorum; $\mathrm{STZ}=$ sztreptozotocin; TNF $\alpha=$ tumornekrózisfaktor-alfa; VLBW = (very low birth-weight) 1500 g alatti születési súly
\end{abstract}

A csecsemőhalandóság kiemelkedő fontosságú mérőszám, amely egy ország egészségügyi ellátórendszerének fejlettségét, a várandósgondozás és az újszülöttellátás színvonalát kifejező, nemzetközileg is számon tartott mutató. Magyarország történelmében először 2011-ben csökkent 5 ezrelék alá, örvendetes módon ez tovább javult (2017-ben tízezer újszülött közül 36 hunyt el egyéves kora elótt), ami az eddig mért legalacsonyabb érték a hivatalos népmozgalmi statisztika történetében [1].

A csecsemőhalálozás kétharmada a koraszülött-ellátással kapcsolatos. A koraszülöttek krónikus utóbetegségei között a legfontosabb és legsúlyosabb elváltozások a retinopathia praematurorum (ROP), a bronchopulmonalis dysplasia (BPD), az intraventricularis haemorrhagia
(IVH), továbbá a periventricularis leukomalacia (PVL). Az egyik legnagyobb magyar neonatalis intenzív központ példája alapján beigazolódott, hogy a magyar adatok a nemzetközi eredményekkel összevethetők [2].

A koraszülöttek túlélési és morbiditási esélyeit elsősorban gesztációs koruk és születési súlyuk befolyásolja. A hazai neonatalis intenzív centrumokban 2013-ban az ápoltak közül 1193 (18,3\%) újszülött születési súlya 1500 gramm alatt volt, ezen belül 507 az 1000 grammot sem érte el. Az 500 gramm alattiak száma 32 fó volt [3].

Az Amerikai Egyesült Államok 24 neonatalis intenzív centrumában végzett vizsgálat megállapította, hogy 1993 és 2012 között aktív kezelésben a 22. hétre születettek $22 \%$-a részesült, ez az arány $97 \%$ fölé emelkedett a 24. gesztációs hétre. A 23. hétre születettek kb. 30\%-a életben maradt, harmaduk súlyos károsodás nélkül [4].

A Pécsi Tudományegyetem Szülészeti és Nőgyógyászati Klinikájának Neonatológiai Tanszékén végzett korábbi felmérések megállapították, hogy a 26. gesztációs héttől a koraszülöttek több mint fele tartós károsodás nélkül éli túl az extrém éretlenséghez társuló problémákat [5], valamint azt, hogy az extrém alacsony súlyú koraszülöttek (1000 g alatti születési súly; extremely low birth-weight - ELBW) hozzávetólegesen 30\%-a szenved hyperglykaemiában [6].

Egy korábbi vizsgálattal igazoltuk, hogy a nagyon alacsony súlyú (1500 g alatti születési súly, very low birthweight - VLBW) hyperglykaemiás koraszülöttek között szignifikánsan gyakrabban fordul elő ROP, mint a normoglykaemiás, a 32. gesztációs hétnél korábban világra jött koraszülöttekben [7]. 


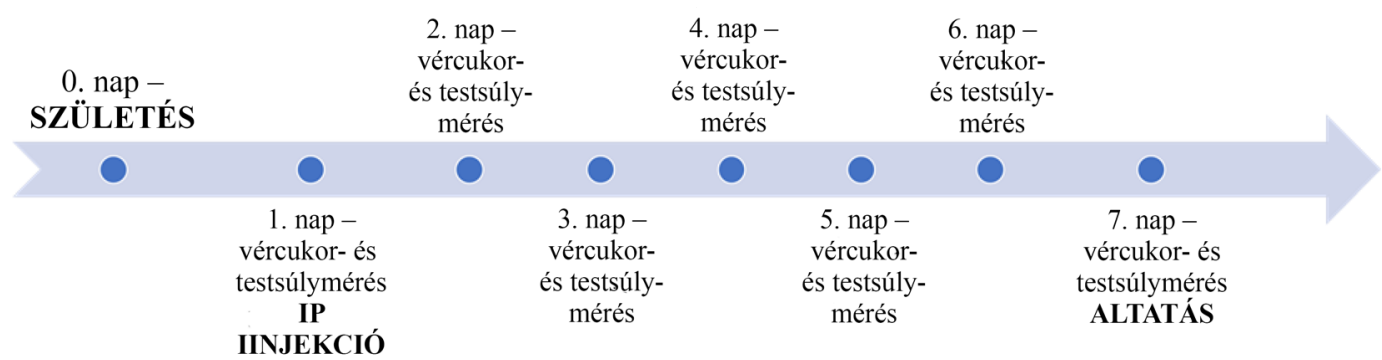

\begin{tabular}{l|l} 
1. ábra & $\begin{array}{l}\text { Állatkísérletes modellünk idővonala } \\
\text { IP }=\text { intraperitonealis }\end{array}$
\end{tabular}

Felmérések alapján a korai hyperglykaemia kiemelt rizikófaktor a ROP kialakulásában [7-12]. A koraszülöttséghez kapcsolódó szövődmények kockázatát jelentősen befolyásolhatja a hyperglykaemia. További tanulmányok a hyperglykaemia és egyéb, koraszülöttekben előforduló komplikációk - neonatalis szepszis [4, 13], gombás fertőzés [14], nekrotizáló enterocolitis (NEC) [13], agyvérzés [14-16] - közti kapcsolatra és a kedvezőtlen fejlődésneurológiai kimenetelre $[17,18]$ hívták fel a figyelmet.

Jelen tanulmányunkban elemezzük a Pécsi Tudományegyetem Klinikai Központjának Szülészeti és Nőgyógyászati Klinikáján múködő Neonatológiai Tanszéken ápolt ELBW-koraszülöttek hyperglykaemiájának gyakoriságát, annak korai és késői szövődményeit. Állatmodell alkalmazásával vizsgáltuk a neonatalis hyperglykaemia cardiovascularis rendszerre gyakorolt hatásait is.

\section{Anyag és módszer}

\section{Betegek}

A Pécsi Tudományegyetem Klinikai Központja Szülészeti és Nőgyógyászati Klinikájának Neonatológiai Tanszékén a 2014. január 1. és 2017. december 31. közötti periódusban 188 ELBW-koraszülöttet ápoltunk; dolgozatunkban adataik elemzésének eredményeiról számolunk be. A hyperglykaemia határának az ismételten 8,5 mmol/1 feletti vércukorértékeket tekintettük az „ágy melletti", teljes vérből történő és/vagy laboratóriumi, plazmából történő vércukor-meghatározás során. A szemészeti vizsgálatok az érvényes szakmai irányelvek alapján, a megszületés után 3-4 hetes korban kezdődtek, és hetente ismétlődtek az általános állapot függvényében. Súlyos ROP-nak a kezelendő retinopathiát tekintettük, ezen esetekben lézeres szemészeti beavatkozás történt. A mútétek a PTE ÁOK Szülészeti és Nőgyógyászati Klinikájának mütőjében, aneszteziológus, szemész és neonatológus szakorvosok jelenlétében történtek. A vizsgálatokat és a mútéteket ugyanaz a szemész szakorvos végezte (G. V.). Üvegtesti mütétre 1 esetben került sor egyéves életkorban.
A tanszék adatbázisa, valamint az e-Medsolution rendszer adatai álltak rendelkezésünkre. Retrospektív vizsgálatunkat a Regionális és Intézményi Kutatásetikai Bizottság engedélyével végeztük (ügyiratszám: 7075PTE 2018).

\section{Állatkisérletek}

Vizsgálatainkat a Pécsi Tudományegyetem Általános Orvostudományi Karának Anatómiai Intézetében végeztük (etikai engedélyszám: BA02/2000-17/2012). Kísérleteinkhez Sprague Dawley patkányokat használtunk; születésük után az állatokat „,keresztalmoztuk”, így egyenlő számú állat került egy alomba, ezzel biztosítottuk az azonos fejlődési ütemet. Az újszülött patkányok fejlettségükben megfeleltethetók egy 24-28 hetes koraszülöttnek [19-21].

A hyperglykaemiás állapotot intraperitonealis sztreptozotocin (STZ)- (Merck KGaA, Darmstadt, Németország) injekció adásával értük el (100 mg/ttkg), a kontrollcsoportba kerülő állatok intraperitonealis citrátinjekciót kaptak a születésüket követő első életnapon a szakirodalomban ismertetett modelleknek megfelelően $[22,23]$ (1. ábra).

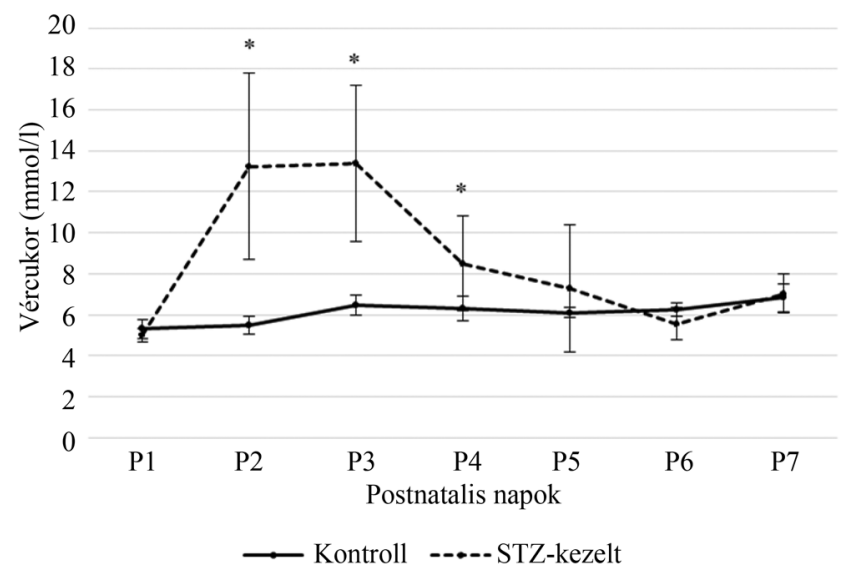

2. ábra A vércukorszint postnatalis változása sztreptozotocinkezelést
követően az első 7 életnapon újszülött patkányban
$\mathrm{STZ}=$ sztreptozotocin
$\left(\right.$ ANOVA, Fisher-féle post-hoc teszt, $\left.{ }^{*} \mathrm{p}<0,05\right)$ 
Csoportonként 12-12 állatot használtunk fel. Az állatokat 12 órás nappali-éjszakai ciklusban, standard müanyag ketrecben $22^{\circ} \mathrm{C}$ fokon tartottuk, ad libitum ellátva ivóvízzel és rágcsálótáppal.

A vércukor-koncentrációt és a testsúlyt naponta ellenőriztük (2. ábra). A vércukorszintet Accu-Check vércukormérővel (Roche Holding Ltd., Bázel, Svájc) mértük, melyhez vért az állatok farkának végéből nyertünk. Az állatokból a 7. életnapon altatást követően egyenként eltávolítottuk az aortát az arcus aortae alsó szakaszától a bifurcatio aortae kezdetéig. Az eltávolítást követően a mintákat 4\%-os paraformaldehid fixálóoldatba helyeztük, majd a beágyazást követően mikrotom segítségével szövettani metszeteket készítettünk, melyeket hematoxilin-eozin oldatokkal festettünk. A falvastagságra vonatkozó méréseket a QCapture Pro 7 (QImaging, Surrey, BC, Kanada) képelemző program segítségével végeztük.

\section{Statisztikai analizis}

A klinikai adatok elemzését páros t-próbával, khi-négyzet-teszttel, az ok-okozati összefüggések vizsgálatát pedig a logisztikus regresszió módszerével végeztük. Az állatkísérletes adatok elemzéséhez az adatok normalitását vizsgáló Shapiro-Wilk-tesztet követően Mann-Whitneypróbát vagy t-próbát végeztünk. A testsúly és a vércukorszint elemzése Kruskal-Wallis- vagy ANOVA-próbával és Fisher-féle post-hoc teszttel történt. Az analízist az IBM SPSS Statistics (Chicago, IL, Amerikai Egyesült Államok) program segítségével végeztük el. A statisztikai elemzővizsgálatoknál az adatok átlag \pm SD értékben kerültek feltüntetésre, a különbségeket p<0,05 értéknél tekintettük szignifikánsnak.

1. táblázat |A hyperglykaemiás és normoglykaemiás ELBW-koraszülöttek klinikai adatainak összehasonlító vizsgálata

\begin{tabular}{lclc}
\hline & $\begin{array}{l}\text { Hyperglykaemia } \\
(62)\end{array}$ & $\begin{array}{l}\text { Normoglykaemia } \\
(126)\end{array}$ & p-érték \\
\hline Gesztációs kor (bét) & $26,32 \pm 2,15$ & $27,58 \pm 2,15$ & $<0,001$ \\
Sziuletési súly (g) & $758,06 \pm 154,09$ & $845,08 \pm 144,36$ & $<0,001$ \\
$\begin{array}{l}\text { Apgar-érték 1 perc } \\
\text { (rangszámátlag) }\end{array}$ & 84,52 & 98,7 & 0,078 \\
$\begin{array}{l}\text { Apgar-érték 5 perc } \\
\text { (rangszámátlag) }\end{array}$ & 87,54 & 97,2 & 0,214 \\
Fiú & $32(51,6 \%)$ & $52(41,3 \%)$ & 0,180 \\
Lány & $30(48,4 \%)$ & $74(58,7 \%)$ & 0,180 \\
Agyvérzés & $32(51,6 \%)$ & $48(38,1 \%)$ & 0,078 \\
Súlyos agyvérzés & $13(20,9 \%)$ & $15(11,9 \%)$ & 0,101 \\
ROP & $39(62,9 \%)$ & $62(49,2 \%)$ & 0,077 \\
Súlyos ROP & $21(33,9 \%)$ & $22(17,4 \%)$ & 0,012 \\
Lézeves szemmútét & $21(33,9 \%)$ & $21(16,7 \%)$ & 0,008 \\
BPD & $35(56,5 \%)$ & $42(33,3 \%)$ & 0,002 \\
Halálozás & $15(24,2 \%)$ & $18(14,3 \%)$ & 0,093 \\
\hline
\end{tabular}

$\mathrm{BPD}=$ bronchopulmonalis dysplasia; ELBW = $1000 \mathrm{~g}$ alatti születési súly; ROP = retinopathia praematurorum

\section{Eredmények}

\section{Az 1000 g alatti súllyal született koraszülöttek klinikai adatainak elemzése}

A 2014. január 1. és 2017. december 31. közötti időszakban 188 ELBW-koraszülöttet ápoltunk, gesztációs koruk és születési súlyuk átlaga $27,2 \pm 2,2$ hét, illetve $816,4 \pm 152,8$ g volt, közülük 33 exitált $(17,5 \%)$. Az esetek csaknem 33\%-ában, 62 koraszülött esetében detektáltunk ismételten hyperglykaemiát, 43 esetben $(22,8 \%)$ alkalmaztunk inzulinkezelést. Az ELBW-koraszülöttek több mint 2/3-ánál (126 gyermeknél) normális tartományban lévő vércukorértékeket mértünk. A hyperglykaemiás újszülöttek születési súlya és gesztációs kora a normoglykaemiásokéhoz viszonyítva szignifikánsan alacsonyabb volt $(\mathrm{p}<0,001)$. Az 1 és 5 perces Apgarértékek vonatkozásában, a nemek közötti eloszlásban, valamint az agyvérzés gyakoriságát vizsgálva sem volt különbség a csoportok között.

Összességében a ROP előfordulásában nem találtunk szignifikáns különbséget a vizsgált csoportok között, azonban a súlyos (III-as és IV-es stádium) ROP-hyperglykaemiás koraszülöttekben szignifikánsan nagyobb mértékben alakult ki az elváltozás $(\mathrm{p}=0,012)$. A ROP miatt arányaiban kétszer annyi lézeres szemmútétet végeztek a hyperglykaemiás betegcsoportban, ez szignifikánsan magasabb volt $(\mathrm{p}=0,008)$. A BPD szignifikánsan nagyobb arányban fordult elő hyperglykaemiás koraszülöttekben $(\mathrm{p}=0,002)$ (1. táblázat).

Mivel a hyperglykaemiás betegek közül a legsúlyosabbak inzulinkezelésre szorultak, adataink retrospektív vizsgálata során a hyperglykaemiás $(\mathrm{HG})$ betegeinket két csoportra osztottuk; inzulinkezelésben részesült (HG-IK), illetve inzulint nem kapott hyperglykaemiás koraszülöttekre (HG-NIK). Eredményeiket összevetettük a normoglykaemiás $(\mathrm{NG})$ csoport adataival (2. táblázat).

Az inzulinkezelt gyermekek gesztációs kora és születési súlya szignifikánsan alacsonyabbnak bizonyult az inzulinkezelésben nem részesült koraszülöttek súlyához viszonyítva. Az 1 és 5 perces Apgar-értékek tekintetében különbséget nem találtunk. Az agyvérzés és a ROP elöfordulása jelentős eltérést nem mutatott a vizsgált csoportok között. A lézeres szemmútét előfordulása $(\mathrm{p}=$ $0,005)$, valamint a mortalitási arány $(\mathrm{p}=0,02)$ az inzulinkezelt betegek körében szignifikánsan magasabb volt, mint a NG csoportban. A BPD incidenciaja is szignifikánsan magasabb volt a fenti 2 csoportot összehasonlítva $(\mathrm{p}=0,001)$.

A túlélő gyermekeket vizsgálva $(\mathrm{n}=155)$ logisztikus regressziós analízissel megállapítottuk, hogy a hyperglykaemia jelentősen (csaknem a kilencszeresére) fokozta a súlyos ROP kialakulásának kockázatát $(\mathrm{p}<0,001)$, amely a gesztációs kor előrehaladtával hetente $33,6 \%$-kal, a születési súly 100 grammos növekedésével $0,5 \%$-kal csökken. Ezzel szemben BPD esetén hozzávetőlegesen 
A hyperglykaemiás, inzulinkezelésben részesült, a hyperglykaemiás, nem inzulinkezelt, valamint a normoglykaemiás ELBW-koraszülöttek klinikai paramétereinek összehasonlító vizsgálata

\begin{tabular}{llllll}
\hline & $\begin{array}{l}\text { HG-IK } \\
(43)\end{array}$ & $\begin{array}{l}\text { HG-NIK } \\
(19)\end{array}$ & $\begin{array}{l}\text { p-érték } \\
\text { (HG-IK vs. } \\
\text { HG-NIK) }\end{array}$ & $\begin{array}{l}\text { NG } \\
(126)\end{array}$ & $\begin{array}{l}\text { p-érték } \\
\text { (NG vs. } \\
\text { HG-IK) }\end{array}$ \\
\hline Gesztációs kor (bét) & $25,93 \pm 2,02$ & $27,21 \pm 2,22$ & 0,029 & $27,58 \pm 2,15$ & $<0,001$ \\
\hline Születési súly (g) & $729,30 \pm 156,47$ & $822,16 \pm 129,96$ & 0,026 & $845,08 \pm 144,36$ & $<0,001$ \\
\hline Apgar-érték 1 perc (rangszámátlag) & 31,49 & 31,53 & 0,994 & 87,74 & 0,124 \\
\hline Apgar-érték 5 perc (rangszámátlag) & 31,86 & 30,68 & 0,796 & 86,49 & 0,328 \\
\hline Agyvérzés & $21(48,8 \%)$ & $11(57,9 \%)$ & 0,511 & $48(38,1 \%)$ & 0,216 \\
\hline ROP & $28(65,2 \%)$ & $11(57,9 \%)$ & 0,587 & $62(49,2 \%)$ & 0,071 \\
\hline Lézeres szemmütét & $16(37,2 \%)$ & $5(26,3 \%)$ & 0,403 & $21(16,7 \%)$ & 0,005 \\
\hline BPD & $27(62,8 \%)$ & $8(42,1 \%)$ & 0,130 & $42(33,3 \%)$ & 0,001 \\
\hline Halálozás & $13(30,2 \%)$ & $2(10,5 \%)$ & 0,131 & $18(14,3 \%)$ & 0,02 \\
\hline
\end{tabular}

BPD = bronchopulmonalis dysplasia; ELBW = $1000 \mathrm{~g}$ alatti születési súly; HG = hyperglykaemiás ELBW-koraszülött; HG-JK = hyperglykaemiás, inzulinkezelésben részesült ELBW-koraszülött; HG-NIK = hyperglykaemiás, inzulint nem kapott ELBW-koraszülött; ROP = retinopathia praematurorum

3. táblázat |A súlyos ROP kialakulását befolyásoló tényezők összefüggésének vizsgálata (logisztikus regresszió) ELBW-koraszülöttekben

\begin{tabular}{lll}
\hline & $\mathrm{p}$ & Esélyhányados [95\% CI] \\
\hline Hyperglykaemia & $<\mathbf{0 , 0 0 1}$ & $\mathbf{8 , 9 3 0}[\mathbf{3 , 5 5 - 2 2 , 4 7 ]}$ \\
BPD & $<\mathbf{0 , 0 0 1}$ & $\mathbf{8 , 6 4}[\mathbf{3 , 4 7 2 - 2 1 , 3 7 2 ]}$ \\
Gesztációs kor & 0,056 & $0,764[0,579-1,007]$ \\
Sziiletési súly & $\mathbf{0 , 0 0 9}$ & $\mathbf{0 , 9 9 5}[\mathbf{0 , 9 9 1 - 0 , 9 9 9 ]}$ \\
\hline
\end{tabular}

$\mathrm{BPD}=$ bronchopulmonalis dysplasia $; \mathrm{CI}=$ (confidence interval) konfidenciaintervallum; ELBW = $1000 \mathrm{~g}$ alatti születési súly; ROP = retinopathia praematurorum

nyolcszoros a ROP súlyos formában történő megjelenésének rizikója $(\mathrm{p}<0,001)$ (3. táblázat).

Az általunk vizsgált 188 ELBW-koraszülöttnél a kóros vesemúködésre utaló klinikai tünetek miatt 34 koraszülöttnél történt szérumkreatinin-meghatározás, közülük 8 exitált. A 34 koraszülöttből 24 gyermeknek ismételten magas vércukorértéke volt. Abból a 17 betegből, akinél kóros kreatininszintet észleltünk, 10-nél hyperglykaemiát is detektáltunk, és 3 exitált.

Az alacsony esetszám miatt nem tudtunk összefüggést kimutatni a hyperglykaemia és a vesekárosodásra utaló emelkedett kreatininszint között.

\section{Állatkisérletes vizsgálataink értékelése}

A STZ-kezelt csoportban hyperglykaemia már a 2. napon kialakult, maximumát a 3 . napon érte el 13,4 $\pm 3,8$ mmol/1 értékkel. Az 5. napra a vércukorszint 7,3 $\pm 0,9$ mmol/1-re csökkent, és ezután a normális tartományban maradt (2. ábra). A kontrollcsoportban nem észleltünk hyperglykaemiát. Az állatok súlyfejlődésében is jelentős különbség volt a csoportok között, a hyperglykaemiás állatok súlya a 7. életnapon átlagosan 14,6 \pm 1,3 gramm, míg a kontrollcsoportban $15,9 \pm 0,5$ gramm volt $(\mathrm{p}<0,05)$.

$\mathrm{Az}$ aortafal szövettani elemzése során a tunica intima és tunica media rétegek vastagságát vizsgáltuk, mivel az érfal ezen rétegeinek módosulása áll a tapasztalt morfológiai elváltozások hátterében. Méréseink alapján a

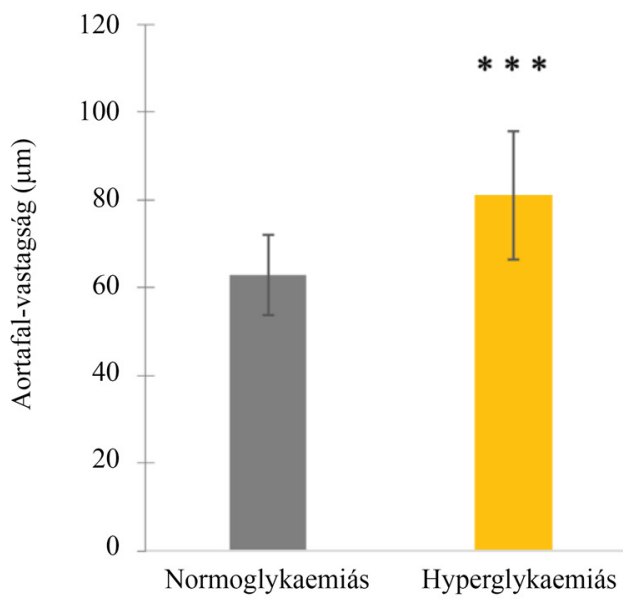

$\mathrm{B} / \mathrm{I}$

B/II.
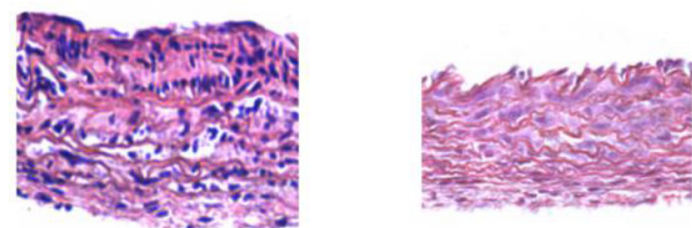

$60 \mu \mathrm{m}$

\begin{tabular}{l|l} 
3. ábra & A) A normoglykaemiás és hyperglykaemiás patkányújszülöttek
\end{tabular} aortafal-vastagságának összehasonlító vizsgálata ( $\mathrm{n}=12$, mindkét csoportban). B) Reprezentatív ábra a szövettani metszetekből (B/I.: hyperglykaemiás ér; B/II.: normoglykaemiás ér)

$\left(\mathrm{t}-\right.$ próba, $\left.{ }^{* * *} \mathrm{p}<0,001\right)$ 
hyperglykaemiás állatok aortájának fala szignifikánsan vastagabbnak bizonyult a normoglykaemiás állatokéhoz képest $(81,1 \pm 14,6$ versus $62,9 \pm 9,1 \mu \mathrm{m} ; \mathrm{p}<0,001)$ (3/A ábra). A hyperglykaemia okozta elváltozások, az aortafal megvastagodása, az emelkedett sejtmagszám látható a bal oldalon $(3 / B / I$. ábra $)$, míg a jobb oldalon egy normoglykaemiás állatból származó aortaszakaszt tüntettünk fel azonos nagyítás mellett $(3 / B / I I$. ábra).

\section{Megbeszélés}

A magas vércukorszintnek napjainkban fokozott jelentősége van, egyrészt az előfordulási gyakoriság növekedésével, másrészt a rövid és hosszú távú komplikációk kialakulásával számolhatunk. A neonatológus szakember is egyre gyakrabban találkozik a cukorháztartás intermittáló vagy folyamatosan fennálló múködési zavarával.

Az 1970-es évek elején megjelent neonatológiai tankönyvek az újszülöttkori hyperglykaemiát a tranziens neonatalis diabetes témakörén belül érintették [24]. Irodalmi adatok alapján az ELBW-koraszülöttekben a hyperglykaemia előfordulási gyakoriságát 20\% és $86 \%$ között detektálták. A jelentős eltérések részben azzal függenek össze, hogy sem a hyperglykaemia definíciójával, sem a vércukorszint-meghatározások módszerével, ajánlott gyakoriságával kapcsolatban nincs egységes állásfoglalás. Egy 2009-ben megjelent tanulmány arról számolt be, hogy az első élethét során folyamatos transzkután vércukor-monitorizálással a VLBW-koraszülöttek $57,9 \%$-ában mérhető magas vércukorszint [25].

Az ELBW-koraszülöttekben a vércukorszint-emelkedés elsősorban az első két élethéten jelentkezik parenteralis glükózbevitel mellett. Ezt követően a gyakoriság jelentősen csökken, ugyanakkor a hyperglykaemiás ELBW-koraszülöttek harmadában 4 hetes kort követően is észlelhető magas vércukorérték; ennek előfordulása 4,1-szer magasabb ELBW-koraszülöttekben, mint az 1000-1499 gramm közti születési súlykategóriában [6]. Ha a 2000 gramm feletti újszülöttekkel hasonlítjuk öszsze, az 1000 gramm alatti születési súlykategóriában a hyperglykaemia incidenciája 18-szor magasabb [26].

Az elmúlt évtizedekben a koraszülött-ellátás fejlődésével hazánkban is jelentősen javultak az ELBW-koraszülöttek életbenmaradási esélyei, az életképesség alsó határa az alacsonyabb gesztációs kor felé tolódik [2].

Az extrém alacsony gesztációs korhoz társuló szövődmények kialakulását jelentősen befolyásolhatja a hyperglykaemia. Ok-okozati kapcsolatot igazoltak a hyperglykaemia jelenléte és a súlyos ROP kialakulása között [7-12]. Állatkísérletes vizsgálatokkal igazolták, hogy az újszülött állatokban előidézett hyperglykaemia a retinában a makrofág sejtek felszaporodásához vezetett, növelte a proinflammatoricus citokinek jelenlétét, a neuronok apoptózisát okozta, valamint gátolta az angiogenezist [22]. Feltételezhető, hogy a hyperglykaemia szerepet játszik koraszülöttekben egyéb szövődmények kialakulásában is. A neonatalis szepszis és a $\operatorname{NEC~}[4,13]$, vala- mint a gombás fertőzés [14], az agyvérzés és a kedvezőtlen fejlődésneurológiai kimenetel vonatkozásában a szerepe bizonyított [14-18].

Koraszülöttekben akár a bazális szükségletet (4-6 $\mathrm{mg} / \mathrm{ttkg} /$ perc) nem meghaladó glükózbevitel is hyperglykaemiához vezethet [26-30]. Az inzulinszintézis zavara miatt fóleg proinzulin termelődik, melynek biológiai aktivitása tizede az inzulinénak. A relatív inzulinhiány miatt a parenteralis úton bevitt glükózt a májsejtek nem képesek hasznosítani [31]. Az inzulinhiány mellett koraszülöttekben a hyperglykaemia veszélyét tovább növeli az inzulinrezisztencia [31, 32], továbbá az inzulinérzékeny szövetek (zsírszövet, váz- és szívizomzat) kis menynyisége és a csökkent perifériás glükózfelvétel. A glükózinfúzió mellett a parenteralis lipidkészítmények a plazma glükózkoncentrációját mintegy 24\%-kal emelik az alapszinthez viszonyítva [33]. Ezzel szemben aminosavkészítmények adása után a vércukorszint csökkenéséről számoltak be (a leucin, a valin, az izoleucin, a glutamin és az arginin fokozza az inzulinszekréciót) [34].

Több tanulmány, köztük saját korábbi vizsgálataink eredménye alapján is összefüggés mutatható ki koraszülöttekben a súlyos fertőzések előfordulása és a hyperglykaemia között $[6,35,36]$. A szepszis, továbbá a súlyos állapottal összefüggő stressz és invazív beavatkozások [37] az inzulinnal ellentétes hatású hormonok (adrenalin, noradrenalin, kortizol) szintjének emelése révén vezethetnek hyperglykaemiához. Az endogén stresszhormonok mellett koraszülöttekben a BPD miatt alkalmazott szteroidkezelés is fontos kóroki tényező a hyperglykaemia kialakulásában [38].

A hyperglykaemiás epizódok mellett fontos kérdés a hyperglykaemia időtartama is. Hyperglykaemiás VLBWkoraszülöttekben folyamatos vércukor-monitorizálással az első élethét során $20,3 \pm 30,1$ órán át észlelhető magas vércukorérték [25].

A bazális glükózigény mellett a proteinanabolizmus támogatására további 2-3 mg/ttkg/perc glükóz szükséges, súlyos betegség esetén az energiaigény magasabb. A cukorháztartás koraszülöttekben észlelhető jellegzetességeit (az inzulinhiány állapota, magas energiaigény) figyelembe véve, parenteralis glükóz és inzulin együttes adása esetén biztosítható, hogy a glükóz megfelelő mennyiségben kerüljön bevitelre, emellett érvényesülhessen az inzulin anabolikus hatása. Beardsall és mtsai tanulmányukban arról számoltak be, hogy korai, az első élethéten alkalmazott elektív inzulinkezeléssel a hyperglykaemia gyakorisága csökkent anélkül, hogy a hypoglykaemiás epizódok előfordulása számottevően emelkedett volna, emellett az inzulinszerü növekedési faktor-1 (IGF1) szintjeinek emelkedését is megfigyelték VLBWkoraszülöttekben. Nyolc európai centrumban (Neonatal Insulin Replacement Therapy in Europe - NIRTUREtrial) 389 VLBW-koraszülöttet vizsgáltak; 195 esetben alkalmazták az elektív inzulinkezelést $(0,05 \mathrm{E} / \mathrm{ttkg}$ /óra az első 7 életnapon), a fennmaradó 194 koraszülött standard kezelésben részesült. A hyperglykaemia alsó határát 
$10 \mathrm{mmol} / 1$ értékben határozták meg. Folyamatos transzkután glükózmonitorizáló szenzort alkalmaztak, amely napi 288 mérést tett lehetővé. Bár a hyperglykaemia gyakorisága csökkent a korai elektív inzulinkezelés mellett, a 28 napon belüli halálozás mérsékelt emelkedése volt megfigyelhető az inzulinnal kezeltek csoportjában [39]. Mindezek figyelembevételével a közelmúltban megjelent áttekintő tanulmányok úgy foglalnak állást, hogy az inzulin rutinhasználata a hyperglykaemia megelőzésére nem javasolható. Ugyanakkor a hyperglykaemia kezelése indokolt, melynek részét képezi az etiológiai tényezők feltárása (magas glükózbevitel, infekció, szteroid) és lehetőség szerinti eliminálása, valamint az inzulin alkalmazása.

A korai postnatalis hyperglykaemia megelőzésére a korai enteralis táplálás lehetőséget nyújthat a glükózprodukció normalizálására, illetve a béltraktus inkretintermelésének fokozására. Preventív jelleggel meg kell előzni minden stresszreakciót kiváltó eseményt, amely jelentősen emelné a vércukorszintet [40].

Zamir és mtsai 580 ELWB-koraszülöttet retrospektív vizsgálatnak vetettek alá, közülük 405 (69,8\%) volt hyperglykaemiás és $175(30,2 \%)$ normoglykaemiás. A gesztációs kor és születési súly átlaga szignifikánsan alacsonyabb, a CRIB score átlaga magasabb volt a hyperglykaemiás csoportban. A csoportot két részre osztva vizsgálták a postnatalis első 28 , valamint az első 70 nap alatti halálozást, és megállapították, hogy az inzulinkezelésben nem részesült hyperglykaemiás koraszülöttek mortalitása szignifikánsan magasabb volt, mint az inzulinkezelésben részesülteké [41]. Arra is van azonban adat, hogy inzulinkezelt koraszülöttekben nagyobb arányban alakul ki ROP, mint a kezelésben nem részesült hyperglykaemiás csoportban [18].

A koraszülöttek vesemúködésének jellegzetességeit figyelembe véve, $12 \mathrm{mmol} / \mathrm{l}$ vércukorérték alatt nem jön létre ozmotikus diuresist előidéző glycosuria. ELBW-koraszülöttekben gyakran alakul ki akut vesekárosodás az első élethetekben, gyakorisága 26-56\% közötti [42, 43].

Jetton és mtsai 4 ország 24 neonatológiai osztálya több mint 2000 betegének adatait feldolgozva megállapították, hogy az akut vesekárosodás gyakorisága 30\% [44].

Harer és mtsai utóvizsgálatokkal azt igazolták, hogy a neonatalis korban akut vesekárosodást elszenvedettek 65\%-ában a vesemúködés zavara 3-7 éves korban kimutatható, diasztolés vérnyomásuk magasabb lehet [45].

Először 2016-ban számoltak be arról, hogy a hyperglykaemia akut vesekárosodást okozhat intenzív osztályon kezelt, súlyosan beteg gyermekekben. Minden 10 $\mathrm{mg} / \mathrm{dl}$ vércukor-emelkedés $10 \%$-kal növelte az akut vesekárosodás lehetőségét [46].

$\mathrm{Az}$ emberi szervezetben az anyagcsere-folyamatok a proximalis tubulusokban és a fotoreceptorokban zajlanak a leggyorsabban, a hyperglykaemia pedig ezeken a területeken gátolja a mitokondriális oxidatív folyamatokat $[46,47]$. Adatok vannak arra vonatkozóan, hogy a hyperglykaemia a vese strukturális fejlődését is befolyásolja [48].

A hyperglykaemia számos korábbi klinikai vizsgálatban bizonyítottan befolyásolta az újszülöttek pszichomotoros és idegrendszeri fejlődését [49-51], valamint állatkísérletes körülmények között sejthalált okozó hatása van $[52,53]$. Állatmodell segítségével igazolták a hosszú távú hyperglykaemiás állapot hatását a nigrostriatalis motoros útvonalra, melynek eredménye a dopaminerg idegsejtek degenerációja, továbbá felvetették a kapcsolat lehetőségét a Parkinson-szerű tünettan kialakulásával is [54].

A hyperglykaemia mint metabolikus hatás az erek falában ún. „hyperglykaemiás memóriát” hoz létre, mely rövid epizódok esetén is hozzájárul maradandó változások kialakulásához (atherosclerosis). Olyan jelátviteli útvonalak aktiválódását idézi elő, melyek prooxidáns és proinflammatoricus gének révén epigenetikus változásokat hoznak létre. Többek között a NFkB indukálásával az érfalban lévő simaizomsejtekben proliferáció és méretbeli növekedés megy végbe. A hyperglykaemia lokális gyulladást okoz az erek falában a felszabaduló IL6 és TNF $\propto$ révén, valamint PKC indukálta szabadgyök-felszabaduláshoz vezet, ami a falszerkezet megvastagodásán túl az endothelréteg diszfunkciójához is hozzájárul [55].

\section{Következtetések}

Retrospektív vizsgálatunkkal megállapítottuk, hogy az $1000 \mathrm{~g}$ alatti súllyal született hyperglykaemiás koraszülöttek gesztációs kora, születési súlya szignifikánsan alacsonyabb, a súlyos ROP előfordulása jelentősen gyakoribb, mint a normoglykaemiás ELBW-koraszülötteké. $\mathrm{Az}$ inzulinkezeltek harmadánál szemészeti mütétre volt szükség, halálozásuk magasabb volt, mint a normoglykaemiás csoporté. Logisztikus regressziós analízissel igazoltuk, hogy a hyperglykaemia jelentősen fokozza a súlyos ROP kialakulásának kockázatát. Állatkísérletes modellen megfigyeltük, hogy a neonatalis hyperglykaemia az aortafal jelentős megvastagodását okozza.

Hyperglykaemia miatt újszülöttkorban kezelésben részesült és gondozásba került koraszülöttek követéses vizsgálata során, testi és szellemi fejlődésük követése mellett, kiemelten fontos a szemészeti kontroll, valamint vesemúködésük és vérnyomásuk ellenőrzése. Már 3 éves korukban magasabb lehet a vérnyomásuk, és a vizeletben is kimutatható elváltozások lehetnek. A korai diagnózist azért tartjuk fontosnak, mert az időben elkezdett kezeléssel a krónikus veseelégtelenség kialakulása megelőzhető.

Anyagi támogatás: A közlemény megírása anyagi támogatásban nem részesült. 
Szerzôi munkamegosztás: T. R.: Adatgyüjtés, a kézirat vázának összeállítása és megszövegezése. S. M. F.: Adatgyưjtés, irodalomkutatás, az adatok feldolgozása, táblázatok szerkesztése. D. T.: Statisztikai analízis. V. R. A.: Állatkísérletek tervezése, kivitelezése, az adatok statisztikai elemzése, ábrák készítése. K. T.: Állatkísérletek tervezése, kivitelezése, adatértékelés és -elemzés, ábrakészítés. H. E., B. D.: Állatkísérletek kivitelezése, adatértékelés és -elemzés. M. B.: Állatkísérletes modell kidolgozása, validálása. F. F., V. G., F. S.: A klinikai adatok értékelése, irodalomkutatás. Gy. J.: Adatértékelés, szerkesztési és tartalmi javaslatok, kritikai elemzés, irodalomkutatás. G. V.: A szemészeti vizsgálatok és mútétek elvégzése, adatelemzés. R. D.: Az állatkísérletes vizsgálatok feltételeinek biztosítása, adatainak egyeztetése és értékelése. E. T.: A vizsgálat megtervezése, irodalomkutatás, a végső forma kialakítása. A cikk végleges változatát valamenynyi szerző elolvasta és jóváhagyta.

Érdekeltségek: A szerzőknek nincsenek érdekeltségeik.

\section{Köszönetnyilvánítás}

A vizsgálatok elvégzését az alábbi kutatási támogatások tették lehetővé: SROP-4.2.2.A-11/1/KONV-2012-0053, GINOP-4.2.2.A-11/1/ KONV-2012-0053, NKFI-EPR K/115394/2015/HU, GINOP2.3.2-15-2016-00021, OTKA 115394, ÚNKP-18-3-I, MTA TKI 14016.

\section{Irodalom}

[1] Central Statistical Office. People's Movement, 2017. [Központ Statisztikai Hivatal. Népmozgalom, 2017] Statisztikai Tükör, 2018. április 20. https://www.ksh.hu/docs/hun/xftp/idosza$\mathrm{ki} /$ nepmozg/nepmozl7.pdf [Hungarian]

[2] Balla, Gy, Szabó M. Chronic morbidities of premature newborns. [Koraszülöttek krónikus utóbetegségei.] Orv Hetil. 2013; 154: 1498-1511. [Hungarian]

[3] Valek A, Szabó M. Report on newborns nursed in Neonatal Intensive Care Units - 2013. [Jelentés a Neonatális Intenzív Centrumokban ápolt újszülöttekről - 2013.] Országos Gyermekegészségügyi Intézet, Budapest, 2015. [Hungarian]

[4] Stoll BJ, Hansen NI, Bell EF, et al. Trends in care practices, morbidity, and mortality of extremely preterm neonates, 1993-2012. JAMA 2015; 314: 1039-1051.

[5] Vida G, Sárkány I, Funke S, et al. Life expectancy of extremely preterm infants. [Extrém alacsony gesztációs korú koraszülöttek életkilátásai.] Orv Hetil. 2007; 148: 2279-2284. [Hungarian]

[6] Gyarmati J, Ertl T, Funke S, et al. Hyperglycemia in extremely low birth-weight infants. [Hyperglycaemia 1000 gramm alatti koraszülöttekben.] Gyermekgyógy. 2004; 55: 633-639. [Hungarian]

[7] Ertl T, Gyarmati J, Gaál V, et al. Relationship between hyperglycemia and retinopathy of prematurity in very low birth weight infants. Biol Neonate 2006; 89: 56-59.

[8] Garg R, Agthe AG, Donohue PK, et al. Hyperglycemia and retinopathy of prematurity in very low birth weight infants. J Perinatol. 2003; 23: 186-194.

[9] Gyarmati J, Tőkés-Füzesi M, Kovács GL, et al. Fructosamine levels and hyperglycemia in preterm neonates. Neonatology 2009; 95: 267-270.
[10] Mohamed S, Murray JC, Dagle JM, et al. Hyperglycemia as a risk factor for the development of retinopathy of prematurity. BMC Pediatr. 2013; 13: 78.

[11] Hyland RM, Komlósi K, Alleman BW, et al. Infantile hemangiomas and retinopathy of prematurity: clues to the regulation of vasculogenesis. Eur J Pediatr. 2013; 172: 803-809.

[12] Slidsborg C, Jensen LB, Rasmussen SC, et al. Early postnatal hyperglycaemia is a risk factor for treatment-demanding retinopathy of prematurity. Br J Ophthalmol. 2018; 102: 14-18.

[13] Kao LS, Morris BH, Lally KP, et al. Hyperglycaemia and morbidity and mortality in extremely low birth weight infants. J Perinatol. 2006 ; 26: 730-736.

[14] Manzoni P, Castagnola E, Mostert M, et al. Hyperglycemia is a possible marker of invasive fungal infection in preterm neonates. Acta Paediatr. 2006; 95: 486-493.

[15] Hays SP, Smith EO, Sunehag AL. Hyperglycemia is a risk factor for early death and morbidity in extremely low birth-weight infants. Pediatrics 2006; 118: 1811-1818.

[16] Auerbach A, Eventov-Friedman S, Arad I, et al. Long duration of hyperglycemia in the first 96 hours of life is associated with severe intraventricular hemorrhage in preterm infants. J Pediatr. 2013; 163: 388-393.

[17] Alexandrou G, Skiöld B, Karlén J, et al. Early hyperglycemia is a risk factor for death and white matter reduction in preterm infants. Pediatrics 2010; 125: e584-e591.

[18] Kaempf JW, Kaempf AJ, Wu Y, et al. Hyperglycemia, insulin and slower growth velocity may increase the risk of retinopathy of prematurity. J Perinatol. 2011; 31: 251-257.

[19] Johnston CC, Walker CD, Boyer K. Animal models of long-term consequences of early exposure to repetitive pain. Clin Perinatol. 2002; 29: 395-414.

[20] Andreollo NA, Santos EF, Araújo MR, et al. Rat's age versus human's age: what is the relationship? Arq Bras Cir Dig. 2012; 25: 49-51.

[21] Sengupta P. The laboratory rat: relating its age with human's. Int J Prev Med. 2013; 4: 624-630.

[22] Kermorvant-Duchemin E, Pinel AC, Lavalette S, et al. Neonatal hyperglycemia inhibits angiogenesis and induces inflammation and neuronal degeneration in the retina. PLoS ONE 2013; 8: e79545.

[23] Furman BL. Streptozotocin-induced diabetic models in mice and rats. Curr Protoc Pharmacol. 2015: 70: 5.47.1-5.47.20.

[24] Dweck HS, Cassady G. Glucose intolerance in infants of very low birth weight. I. Incidence of hyperglycemia in infants of birth weights 1,100 grams or less. Pediatrics 1974; 53: 189-195.

[25] Iglesias Platas I, Thió Lluch M, Pociello Almiñana N, et al. Continuous glucose monitoring in infants of very low birth weight. Neonatology 2009; 95: 217-223.

[26] Louik C, Mitchell AA, Epstein MF, et al. Risk factors for neonatal hyperglycemia associated with $10 \%$ dextrose infusion. Am J Dis Child. 1985; 139: 783-786.

[27] Cowett RM, Farrag HM. Selected principles of perinatal-neonatal glucose metabolism. Semin Neonatol. 2004; 9: 37-47.

[28] Tyrala EE, Chen X, Boden G. Glucose metabolism in the infant weighing less than 1100 grams. J Pediatr. 1994; 125: 283-287.

[29] Ward Platt M, Deshpande S. Metabolic adaptation at birth. Semin Fetal Neonatal Med. 2005; 10: 341-350.

[30] Sunehag A, Gustafsson J, Ewald U. Very immature infants (< or $=30 \mathrm{Wk})$ respond to glucose infusion with incomplete suppression of glucose production. Pediatr Res. 1994; 36: 550-555.

[31] Mitanchez-Mokhtari D, Lahlou N, Kieffer F, et al. Both relative insulin resistance and defective islet $\beta$-cell processing of proinsulin are responsible for transient hyperglycemia in extremely preterm infants. Pediatrics 2004; 113: 537-541.

[32] Mitanchez D. Glucose regulation in preterm newborn infants. Horm Res. 2007; 68: 265-271. 
[33] Sunehag AL. The role of parenteral lipids in supporting gluconeogenesis in very premature infants. Pediatr Res. 2003; 54 : $480-486$.

[34] Kairamkonda VR, Khashu M. Controversies in the management of hyperglycemia in the ELBW infant. Indian Pediatr. 2008; 45: 29-38.

[35] Manzoni P, Castagnola E, Mostert M, et al. Hyperglycemia is a possible marker of invasive fungal infection in preterm neonates. Acta Paediatr. 2006; 95: 486-493.

[36] Fanaroff AA, Korones SB, Wright LL, et al. Incidence, presenting features, risk factors and significance of late onset septicemia in very low birth weight infants. The National Institute of Child Health and Human Development Neonatal Research Network. Pediatr Infect Dis J. 1998; 17: 593-598.

[37] Lilien LD, Rosenfield RL, Baccaro MM, et al. Hyperglycemia in stressed small premature neonates. J Pediatr. 1979; 94: 454459.

[38] Yeh TF, Lin YJ, Hsieh WS, et al. Early postnatal dexamethasone therapy for the prevention of chronic lung disease in preterm infants with respiratory distress syndrome: a multicenter clinical trial. Pediatrics 1997; 100: E3.

[39] Beardsall K, Vanhaesebrouck S, Ogilvy-Stuart AL, et al. Prevalence and determinants of hyperglycemia in very low birth weight infants: cohort analyses of the NIRTURE study. J Pediatr. 2010; 157: 715-719.e3.

[40] Lemelman MB, Letourneau L, Greeley SA. Neonatal diabetes mellitus: an update on diagnosis and management. Clin Perinatol. 2018; 45: 41-59.

[41] Zamir I, Tornevi A, Abrahamsson T, et al. Hyperglycemia in extremely preterm infants - insulin treatment, mortality and nutrient intakes. J Pediatr. 2018; 200: 104-110.el.

[42] Arcinue R, Kantak A, Elkhwad M. Acute kidney injury in ELBW infants ( $<750$ grams) and its associated risk factors. J Neonatal Perinatal Med. 2015; 8: 349-357.

[43] Lee CC, Chan OW, Lai MY, et al. Incidence and outcomes of acute kidney injury in extremely-low-birth-weight infants. PLoS ONE 2017; 12: e0187764.

[44] Jetton JG, Boohaker LJ, Sethi SK, et al. Incidence and outcomes of neonatal acute kidney injury (AWAKEN): a multicentre, multinational, observational cohort study. Lancet Child Adolesc Health 2017; 1: 184-194.

[45] Harer MW, Pope CF, Conaway MR, et al. Follow-up of Acute kidney injury in Neonates during Childhood Years (FANCY): a prospective cohort study. Pediatr Nephrol. 2017; 32: 10671076.

[46] Gordillo R, Ahluwalia T, Woroniecki R. Hyperglycemia and acute kidney injury in critically ill children. Int J Nephrol Renovasc Dis. 2016; 9: 201-204.

[47] Fu Z, Löfquist CA, Liegl R, et al. Photoreceptor glucose metabolism determines normal retinal vascular growth. EBMO Mol Med. 2018; 10: 76-90.

[48] Cunha AR, Aguila MB, Mandarim-de-Lacerda C. Effects of early postnatal hyperglycaemia on renal cortex maturity, endothelial nitric oxide synthase expression and nephron deficit in mice. Int J Exp Pathol. 2008; 89: 284-291.

[49] Fösel S. Transient and permanent neonatal diabetes. Eur J Pediatr. 1995 ; 154: 944-948.

[50] Duvanel CB, Fawer CL, Cotting J, et al. Long-term effects of neonatal hypoglycemia on brain growth and psychomotor development in small-for-gestational-age preterm infants. J Pediatr. 1999; 134: 492-498.

[51] Camprubi Robles M, Campoy C, Garcia Fernandez L, et al. Maternal diabetes and cognitive performance in the offspring: a systematic review and meta-analysis. PLoS ONE 2015; 10: $\mathrm{e} 0142583$.

[52] Zhao J, Del Bigio MR, Weiler HA. Maternal arachidonic acid supplementation improves neurodevelopment in young adult offspring from rat dams with and without diabetes. Prostaglandins Leukot Essent Fatty Acids 2011; 84: 63-70.

[53] Rosa AP, Mescka CP, Catarino FM, et al. Neonatal hyperglycemia induces cell death in the rat brain. Metab Brain Dis. 2018; 33: 333-342.

[54] Renaud J, Bassareo V, Beaulieu J, et al. Dopaminergic neurodegeneration in a rat model of long-term hyperglycemia: preferential degeneration of the nigrostriatal motor pathway. Neurobiol Aging 2018; 69: 117-128.

[55] Paneni F, Beckman JA, Creager MA, et al. Diabetes and vascular disease: pathophysiology, clinical consequences, and medical therapy: part I. Eur Heart J. 2013; 34: 2436-2443.

(Ertl Tibor dr., Pécs, Édesanyák útja 17., 7624 e-mail: tibor.ertl@aok.pte.hu)

\section{"Salus aegroti suprema lex esto." (A legfőbb törvény a beteg üdve legyen.)}

A cikk a Creative Commons Attribution 4.0 International License (https://creativecommons.org/licenses/by/4.0/) feltételei szerint publikált Open Access közlemény, melynek szellemében a cikk bármilyen médiumban szabadon felhasználható, megosztható és újraközölhető, feltéve, hogy az eredeti szerzỏ és a közlés helye, illetve a CC License linkje és az esetlegesen végrehajtott módositások feltüntetésre kerülnek. (SID_1) 